\title{
Reformationen og køn
}

\author{
Kvinder og kirkens embede
}

\author{
Lektor, ph.d. \\ Else Marie Wiberg Pedersen
}

\begin{abstract}
This article will combine three anniversaries, namely the 500-anniversary of the beginning of Luther's reformation, the 75-anniversary of the establishment of theology at Aarhus University, and, not least, the 70-anniversary of the admission of women to the ordination in the Evangelical-Lutheran church in Denmark. The article will thus fall in three main parts. The first part will treat Luther's theology of ministry with regard to gender and the role of women in the church. The next part will highlight what role theology and gender played when women were finally admitted to the ordination. Finally, Regin Prenter's (the first professor in dogmatics at Aarhus University) theology of ministry pertaining to women will be analysed. The aim is that of showing how later generations of Lutherans were often more conservative than the reformer, introducing arguments against women's ordination that were irreconcilable with Luther's theology, particularly in the $20^{\text {th }}$ century.
\end{abstract}

Keywords: Luther - Prenter - Reformation and gender - priesthood of all believers - women and ministry - women and ordination

Det er ikke ofte, man kan kombinere tre jubilæer i en og samme artikel, men netop her i 2017 kan vi fejre tre vigtige begivenheder, som, vil jeg hævde, hænger nøje sammen. Først og fremmest er det 500-året for reformationens begyndelse med Martin Luther som frontfigur. Når Teologi i Aarhus kan fejre 75-års-jubilæum, mens lovene om ordination af og adgang for kvindelige præster i den danske folkekirke har 70-års-jubilæum, så hænger det faktisk sammen med Luthers reformatoriske tanker om en solid, akademisk uddannelse af kirkens forkyndere og humanisering af præsteembedet.

I nærværende artikel vil jeg forbinde disse tre væsentlige begivenheder ved først at belyse, hvordan Luthers teologi banede vejen for, at der kom kvindelige præster i den danske folkekirke som den første store evangelisk-lutherske kirke i verden. Dernæst vil jeg analysere hvordan Regin Prenter, den første professor i dogmatik ved teologi på Aarhus Universitet, tolkede kirkens embede 10 år efter de første ordinationer af kvindelige præster i 1948. 
Selvom dette spørgsmål efterhånden kan synes uaktuelt i en dansk folkekirkesammenhæng, hvor kvinder siden 2010 har udgjort ca. halvdelen af præstestanden, så spiller det stadig en stor rolle som et teologisk diskussionspunkt på verdensplan. Ikke blot er det stadig ikke muligt for kvinder at blive præster i den romersk-katolske kirke og de ortodokse kirker. Ordination af kvinder møder fortsat modstand i nogle lutherske kirker som fx Lutheran Church - Missouri Synod i USA. Da Porvoo-erklæringen om gensidig anerkendelse og samarbejde mellem de nordiske og baltiske lutherske kirker og de britiske anglikanske kirker blev formuleret i 1993, bragte man i et forord et særligt forbehold med hensyn til anerkendelse af kvindelige præster og biskopper, samt alle præster ordineret af kvindelige biskopper. ${ }^{1}$ Der er stadig 30 af Det Lutherske Verdensforbunds medlemskirker, der ikke anerkender kvindelige præster. Det gælder fx den evangelisklutherske kirke i Letland (ELCL), som er medlem af Det Lutherske Verdensforbund (LVF) og har fuld observatørstatus i Porvoo-fællesskabet. ELCL afbrød sin praksis siden 1975 med at ordinere kvinder i 1993, ironisk nok året efter at den britiske anglikanske kirke og den finske lutherske kirke tillod kvindelige præster, og samme år som LVF udsendte en rapport, der indskærpede, at der ikke findes en særlig embedsteologi for kvinder. ${ }^{2}$ ELCL tog det sidste skridt tilbage ved den 4. juni 2016 at indføre et totalt forbud mod ordination af kvinder med henvisning til Bibelen og den historiske episkopale succession, som man mener at have sikret sig via Svenska Kyrkan.

De seneste års begivenheder har vist, hvor hurtigt liberale og demokratiske tiltag kan rulles tilbage, hvis man ikke værner om dem og gennemtænker deres værdi. Det er således stadig påkrævet at gennemtænke den luthersk reformatoriske teologi vedrørende det kirkelige embede og embedets hvem, ikke mindst nu hvor kristenheden flytter til den sydlige halvkugle med et traditionelt konservativt syn på køn. ${ }^{3}$ Kampen for, at kvinder ses som jævnbyrdige med mænd og er ligefuldt mennesker i alle livets forhold, har været lang og sej. I Danmark skulle der gå 430 år, før man for alvor realiserede de ligheds- og frihedstanker, som Luthers teologi rummer.

1. Se David Tustin og David Furberg, "Introduction", Together in Mission and Ministry. The Porvoo Common Statement with Essays on Church and Ministry in Northern Europe, red. David Tustin og David Furberg (London: Church House Publishing 1993), 4.

2. LVF, Ministry. Women. Bishops (Geneve: The Lutheran World Federation 1993).

3. Jf. Musimbi Kanyoro, "Communities of Gender and the Communion of the Church", Communion, Community, Society. The Relevance of the Church, red. Wolfgang Greive (Geneve: LWF 1998), 33-47. 
Kønnet er ikke til diskussion: Luthers embedsteologi

Overordnet set satte Luther en ny dagsorden ved at tage afstand fra den traditionelle nedvurdering af kvinder og i stedet understrege kvinders status som virkelige mennesker. Således opvurderer han mange af de kendte kvindefigurer i Bibelen og fremstiller dem som sande Kristi disciple, fordi de er i stand til at erkende fejl og rette dem. Det gælder Eva, Sara, Lea og Lots hustru fra Det Gamle Testamente og Maria, Maria Magdalena og Martha og Maria fra Det $\mathrm{Ny}$ Testamente. I modsætning til de traditionelle tolkninger ser Luther dem alle som virkelige kvinder, der på grund af deres tro bliver fuldkomne Kristusdisciple netop i deres (fejlbarlige) menneskelighed. Det gør dem til realiserbare idealer for alle mennesker. Det samme gælder for Maria, der i Luthers udlægning ganske vist er Guds mor, men det er hun, fordi hun er en rigtig kvinde fra lave kår. Det er i kraft af sin sande menneskelighed og sit trofaste discipelskab, at Maria bliver mor til Guds sande menneskebarn (Menschenkind). ${ }^{4}$ Bemærk, at Luther ikke anvender termen Menneskesøn, men netop understreger Kristi karakter af menneskebarn. I sine centrale teologiske udsagn lægger Luther vægt på menneskets, ikke mandens, betydning. I den forstand bygger Luthers embedssyn på en konsekvent real inkarnationsteologi, der rækker ud over en almindelig skabelsesteologi. Luther accentuerer nemlig ikke alene, at mand og kvinde er skabt lige i Guds billede (imago Dei) som partnere, ${ }^{5}$ men også at Kristus blev inkarneret som et sandt menneske (anthropos/homo/Mensch), født af en sand kvinde. Faktisk pointerer han aldrig, at Kristus var en mand (aner/vir/Mann), altid at Kristus var sandt menneske (jf. 1 Pet 2 og Nicænums sarxothenta og enanthropesanta). Ligeledes fremhæver han aldrig hverken Kristi eller apostlenes køn i forbindelse med embedet. Embedets funktion med formidling af Guds ord om tilgivelse er ikke afhængig af dets hvem og er ikke kønsbundet. Det kræver et menneske, hvis personlige beskaffenhed er uden betydning.

Det er denne Luthers radikalt reale inkarnationskristologi, der sammen med hans sola scriptura-princip får vidtrækkende betydning for hans embedsteologi. Luthers sola scriptura-princip var jo styret af hans forståelse af skriften som evangelium. Med målestokken, om skrifterne "driver på Kristus", ${ }^{6}$ krævede han sin frie ret til selv at tolke skriften: "Jeg anerkender ingen faste regler for tolkningen af Guds

4. Luther, "Kirchenpostille”, WA 10,1, 352-369; "Magnificat", WA 7, 538-604. I sidstnævnte tekst gør Luther Maria og Marias Gud til det spejl, fyrsten bør spejle sig i.

5. Luther, "Text der Genesisvorlesung”, WA 42, 51.

6. Luther, "Vorrede zum Jakobus- und Judasbrief", WA DB 7, 384. 
ord, da Guds ord, som lærer frihed i alle andre sager, ikke kan være bundet [...] De, som tilskriver dig [pave Leo] alene retten til at tolke skriften, tager fejl."7

Ifølge Luther er embedet til for evangeliets og sakramenternes skyld, fordi der skal være nogen, som på en ret og rimelig måde kan formidle ordet og meddele sakramenterne (jf. CA 4 og 5). Embedet skal altså være der af praktiske grunde, men i sig selv er embedet og ordinationen ikke et sakramente endsige helligt. Det er dermed en misforståelse at anse præsten for en Kristi stedfortræder (vicarius Christi), for det kan man kun være, hvis Kristus er fraværende. Men tror man på den nærværende Kristus, er man i lighed med apostlene servus Christi.

Se, hvor forskellig Kristus er fra sine efterfølgere (successores), skønt de alle vil være hans stedfortrædere. Jeg frygter, at de fleste af dem i for høj grad har været hans stedfortrædere. Man er nemlig kun stedfortræder, når ens overordnede er fraværende. Hvis paven regerer, mens Kristus er fraværende og end ikke bor i hans hjerte, hvad andet er han så end Kristi stedfortræder (Vicarius Christi absentis)? Hvad andet er kirken under en sådan [stedfortræder] end en folkemængde uden Kristus? Sandt at sige, hvad er en sådan stedfortræder andet end Antikrist eller en afgud? Apostlene gjorde rettere, idet de kaldte sig tjenere for den nærværende Kristus (servos Christi praesentis), ikke stedfortrædere for den fraværende! ${ }^{8}$

Heller ikke Paulus kaldte sig Kristi stedfortræder, men tjener (diaconus). Således er præsten ordets tjener (minister verbi) og ikke en stedfortræeder for den historiske mand, Jesus, men repræsentant for den nærværende, inkarnerede Kristus i ordet, den kødeliggjorte Logos (in verbo Christi-repræsentationen). Luthers pointe er, at Gud i Kristus ønskede at blive kendt som et menneske (ikke som en mand), og at præsten derfor må være et almindeligt menneske.

7. Luther, "Epistola Lutheriana ad Leonem Decimum summum pontificem. Tractatus de libertate christiana", WA 7, 47-48: "Deinde leges interpretandi verbi dei non patior, cum oporteat verbum dei esse non alligatum, quod libertatem docet omnium aliorum [...] Errant, qui tibi soli scripturae interpretandae ius tribuunt." Danske oversættelser er mine.

8. Luther, WA 7, 48: "Vide, quam dispar sit Christus suis successoribus, cum tamen omnes velint eius esse vicarii. Et metuo, ne revera plurimi eorum sint et nimium serio Vicarii eius. Vicarius enim absentis principis est. Quod si pontifex absente Christo et non inhabitante in corde eius praesit, quid aliud quam Vicarius Christi est? At quid tum illa Ecclesia nisi multitudo sine Christo est? Quid vero talis Vicarius nisi Antichristus et Idolum est? Quanto rectius Apostoli, qui se servos Christi appellant praesentis, non Vicarios absentis!" 
Hermed lægger Luther vægten på det almene præstedømme og dåben som det sande ordinationssakramente, hvor alle troende fødes som konger og præster" og bliver Ordets sande successores: "Alle kristne er præster (sacerdotes), og alle præster er kristne" med pligt og ret til "at lære, prædike og forkynde Guds ord, døbe, konsekrere og uddele nadveren, binde og løse synder, bede for andre, bringe sig selv som offer og prøve alle lærere og ånder." ${ }^{10}$ Prædikenembedet (presbyteros, Pfarrer) vælges fra det almene præstedømmes midte, alle kaldet af Gud. ${ }^{11}$ Netop denne markante teologi om det almene præstedømme, som gør alle kristne ansvarlige for det særlige embede, betyder, at kvinder er fuldt ud inkluderet og må tale, når ingen mand gør det. ${ }^{12}$ En revolutionerende tanke i 1500-tallet, og da også en af de 41 formuleringer, Luther bandlyses for i 1521. Pavekirken fordømmer ham for ikke at anse pave og biskop for mere end selv den ringeste præst, så fx bodssakramentet kan varetages af "enhver kristen, om det så er en kvinde eller et barn." ${ }^{13}$ Om det er grunden til, at denne lære ikke er medtaget i Den augsburgske Bekendelse, er uvist, men den forbliver en både væsentlig og uomgængelig del af Luthers embedsteologi. Luther understreger endvidere vigtigheden af den rette, offentlige kaldelse til det særlige embede. I sin opregning af kirkekendetegn (Guds ord, dåb, nadver, absolution og selve embedet indstiftet af Gud til at meddele disse gaver) pointerer Luther, at de ikke er afhængige af, hvem eller hvordan "tjeneren" er - altså af, hvem der rækker sakramenterne eller absolverer. I stedet afhænger ordet og sakramenterne af modtageren, og af at de gives offentligt. Særlig vigtigt er Guds ord, ved hvilket de andre står og falder, for det er "det ydre ord mundtligt forkyndt af mennesker, af dig og mig." 14

Luther afviser en sakramental forståelse af ordinationen og dermed også, at den ordinerede præst skulle have antaget en ny ontologisk

9. Luther, "De captivitate babylonica", WA 6, 497-573.

10. Luther, "De instituendis ministris ecclesiae", WA 12, 180: "Sunt autem sacerdotalia official ferme haec: docere, praedicare annunciareque verbum dei, baptisare, consecrare seu Eucharistiam ministrare, ligare et solver peccata, orare pro aliis, sacricifare et iudicare de omnium doctrinis et spiritibus." Jf. "Luther an Spalatin", WA, BR 1, 595.

11. Ibid. og Luther, "In epistolam S. Pauli ad Galatas", WA 40, I, 59

12. Luther, "Vom Misbrauch der Messe", WA 8, 498.

13. Leo X, "Errores Martini Luther", Denzinger-Schönmetzer, Enchiridion symbolorum (Freiburg/Rom: Herder 1963), 359 (nr. 753): "In sacramento paenitentiae ac remissione culpae non plus facit Papa aut episcopus, quam infimus sacerdos: immo, ubi non est sacerdos, aeque tantum quilibet Christianus, etiamsi mulier aut puer esset."

14. Luther, "Von den Konziliis und Kirchen", WA 50, 624-634, her 629: "Wir reden aber von dem eusserlichen wort, durch menschen, als durch dich und mich muendlich gepredigt." Jf. Luther, "Von der Winkelmesse”, WA 38, 241. 
hellighed som en uudslettelig karakter (character indelebilis). Ifølge Luther er en sådan tanke om en kvalitativ og ontologisk kløft mellem den ordinerede præst og lægfolket absurd. Ikke bare er den uden hold i skriften, den er tillige udtryk for en total uvidenhed om Kristus, og hvad det er at være kristen:

Enhver kristen er salvet med Helligåndens olie og helliget på legeme og sjæl, og i oldkirken modtog alle eukaristien med deres hænder på samme måde som præster i dag rører brødet og kalken. Det er ikke andet end overtro, som nu til dags blæser det op til en stor sag, hvis en lægperson rører kalken eller alterklædet. End ikke nonner, hellige jomfruer, er det tilladt at vaske alterdugen. Se dog, for Guds skyld, hvor meget denne ordinationens sakrosankte hellighed har bredt sig! Jeg forventer, at lægfolk i fremtiden kun vil få lov at røre alteret, når de skal ofre penge. Jeg er ved at eksplodere, når jeg tænker på disse helt forfærdelige menneskers totalt uhellige tyranni, hvordan de med sådanne barnlige narrestreger spotter og spolerer den kristne tros frihed og ære. ${ }^{15}$

Absurditeten ved tanken om det hellige offerembedes afstand fra den almene kristne understreges af, at end ikke de hellige jomfruer kan røre kalk og alter. Det sidste er vigtigt, fordi det peger på et bevidst opgør med traditionen for at udelukke kvinder fra det præstelige embede overhovedet grundet katolsk embedsteologis vægt på den mandlige offerpræst (sacerdos) ved alteret. Det er tydeligt, at Luther til stadighed kæmper med det traditionelle syn på kvinder, han har arvet, både når det gælder brugen af Bibelens kvindefigurer og behandlingen af sin samtids kvinder - som når han voldsomt kritiserer tidens gængse aristoteliske syn på kvinder, Guds smukkeste værk, som uperfekte mænd ${ }^{16}$ og forskelsbehandling af kvinder ved altergang, hvortil kvinder lige såvel som mænd er præsteligt klædt. ${ }^{17}$

15. Luther, WA 6, 566: "At Christianus quilibet oleo sancti spiritus unctus et sanctificatus est corpore et anima, et olim sacramentum manibus tractabat non minus quam nunc sacerdotes faciunt, licet nostra superstitio laicis nunc magnum reatum iniiciat, si vel calicem nudum aut corporale tetigerit, nec Moniali quidem, sanctae virgini, liceat lavare pallas altaris et lintheamina sacra. Vide per deum sacrosanctam ordinis huius sanctitatem, quantum profecerit. Futurum spero, ut nec altare liceat attingere laicis, nisi dum nummos obtulerint. Ego pene dirumpor cogitans has impiissimas hominum temeratissimorum tyrannides tam nugacibus et puerilibus nugis libertatem et gloriam Christianae religionis illudentium et pessundantium." 16. Luther, WA 42, 53: “... Aristoteles appellat mulierum virum occasionatum, et alii monstrum dicunt. Sed sint ipsi monstra et monstrorum filii, qui sic calumniantur et rident creaturam Dei, in qua ipse Deus delectatus est, tanquam in nobilissimo opere."

17. Luther, WA 50, 631: "ob du mans bilde oder weibs bilde [...] ist gnug, das du geweihet und gekresemet seiest mit dem hohen, heiligen kresem Gottes, des worts 


\section{Et køn(ne)t embede?}

Når Luther i tre korte tekstpassager fra 1530'erne undtager kvinder fra prædikenembedet, kan det derfor ses som udtryk for en splid i Luther selv. Hvordan kan fortaleren for det almene embede have et så traditionelt syn på kvinder og deres rolle uden for familie og hjem? Hvordan kan han fastholde, at præstens hvem er ligegyldigt, og samtidig undtage kvinder? Luther bliver i en vis forstand fanget af sit sola scriptura-princip, hvis han blot vil følge Paulus i 1 Kor 14, 34 og (tror han) i 1 Tim 3, 2, selvom de ikke just "driver på Kristus." Det synes at have voldt ham problemer. Man kan nemlig også hæfte sig ved, at Luther faktisk indrømmer kvinder en væsentlig præstelig rolle, de ikke før har haft. Luther kan ganske vist fastslå, at kvinder ikke skal prædike offentligt, og så alligevel skal, når ingen mand kan. Men også at de nok kan være profeter, der øver sjælesorg og underviser i skriften. ${ }^{18}$ Ligesom han straks efter kan fastslå, at en erfaren karteusermunk ikke er bedre end en malkepige. ${ }^{19} \mathrm{I}$ "Von den Konziliis und Kirchen" lader Luther Helligånden undtage kvinder fra prædikenvirksomhed (sammen med børn og udygtige folk), medmindre der er tale om en nødsituation. ${ }^{20}$ Det er "dygtigheden", altså uddannelsen til præst, det handler om, sådan som den videre tekst afslører. Luther bruger nemlig mere plads på at fremhæve, at en syvårig pige undervist $\mathrm{i}$ en luthersk skole vil være væsentlig dygtigere til den kristelige lære og skrift end nogen af pavens embedsindehavere. Når Luther derpå konkluderer, at ingen skal agte på, hvem og hvordan embedspersonen er, da alt er givet til den, der får det gennem embedet, har han allerede absolveret sin undtagelsespassage. Luthers pointe er ikke at udelukke kvinder fra embedet; det er snarest et "aber dabei", fordi spørgsmålet om dygtige og uddannede personer er væsentligt i hans opgør med romerkirkens embedsforståelse. Dette stemmer fint overens med hans kamp for uddannelse af både piger og drenge på tysk såvel som latin, ${ }^{21}$ samt hans rekruttering af kvindelige lærere til sko-

Gottes und der Tauffe, auch dieses Sakraments, da bistu hoch und herrlich gnug gesalbet und priesterlich gekleidet."

18. Luther, "Predigten des Jahres 1531: Sermon über Joel 2, 28", WA 34.1, 482;

"Ein Brief D. Martin Luther von den Schleichern und Winkelpredigern", WA 30, 524.

19. Luther, WA 34.1, 485: "Cartheuser, qui 40 annis in ordine zc. sol nichts besser sein quam ancilla, quae tregt der kue gras zc."

20. Luther, WA 50, 633: "War ists aber, da in diesem stueck der heilige Geist ausgenommen hat Weiber, kinder und untuechtige Leute, sondern allein tuechtige mans Personen hiezu erwelet (ausgenomen die not)."

21. Bl.a. Luther, "An die Ratherren aller Städte deutsches Lands, dass sie christliche Schulen aufrichten und erhalten sollen", WA 15, 9-53. 
lerne, hvad humanister som Erasmus opponerede mod. ${ }^{22}$ At piger og kvinder generelt fik mulighed for bedre og højere uddannelse blev i sidste instans indgangen til det særlige embede (jf. nedenfor).

Centralt i "Von den Konziliis und Kirchen" står igen opgøret med den ifølge Luther misforståede sakralisering af embedet. Når præster gennem cølibat menes at træde i Guds og Kristi sted i den guddommelige natur, gør man sig i virkeligheden til nestorianere. ${ }^{23} \mathrm{Når}$ "papisterne" anser embedspersonerne for at være kirkens brudgom, sådan at de ved ordinationen indgår et sakramentalt ægteskab med kirken som brud, har de helt misforstået Pauli ord i Efes 5. Ifølge Luther er alene Kristus kirkens brudgom. Kristus bliver ét legeme med kirken analogt med en mand og kvinde i ægteskabet. Kristi sammensmeltning med kirken er et usynligt mysterium, som kun kan tros, og som forklares med ægteskab som et sprogbillede (ein figur). ${ }^{24}$ Her ligger et stærkt opgør med en forståelse af embedet som særlig helligt og mandligt. Det understreger Luther med tilføjelsen af det markante udsagn, at embedspersonen hverken er med til at forringe eller forbedre Guds ord og sakramente, da det alt sammen tilhører Kristus og øves af Helligånden. ${ }^{25}$ Luther placerer i stedet embedet midt i et normalt familie- og hverdagsliv, accentueret i hans opgør med cølibat og munkeliv som en status perfectionis. Præsten skal i alle henseender være et menneske (homo), kaldet offentligt af mennesker (jf. CA 14: rite vocatus). ${ }^{26}$

Det er en nøgleforståelse i Luthers teologi, at embedets hvem sammen med en lang række andre "ydre ting" (eusserliche Dinge) er et adiaforon og således angår ius circa sacra. Blot skal der være en person til at varetage prædikenembedet, valgt og kaldet af flertallet i menigheden på en sådan måde, at alt foregår fredeligt og ordentligt, men også frit. ${ }^{27}$ I Luthers teologi lægges vægten på medlemmernes frihed til at kalde en duelig person til prædikenembedet. Mens Luther fortsat forstår embedet som guddommeligt indstiftet, humaniserer han det. Mens den katolske forståelse af embedet er baseret på en ordination bundet til et hierarki af sakrale mænd (officium sacerdotalis), baserer Luther embedet på dåben som det sande ordinationssakramente

22. Jf. Steven Ozment, When Fathers Ruled (Cambridge/Massachusets/London: Harvard University Press 1983), 153-154.

23. Luther, WA 50, 635-641.

24. Ibid., 637-641 (641).

25. Ibid., 634 .

26. Luther, WA 12, 180.

27. Luther, WA 50, 649-650: “...sols alles friedlich, oerdendlich zugehen, und doch frey sein, wo es zeit, Person oder ander ursachen foddern zu endern. Da selbs folget der hauffe auch mit eintrechtiglich, weil es (wie gesagt) keinen Christen heiliger, noch unheiliger macht". 
bundet til Kristus og det lige fællesskab af kristne. Embedet indgår hos Luther ikke i en historisk succession af biskopper, men i rækken af følgere (successores) af evangeliet med den funktion at udøve ordets tjeneste (ministerium verbi). Mens det katolske vicarius Christiembede er stedfortrædende for Kristi guddommelige natur (hvorfor Luther kalder dem nestorianere, da de har efterladt Kristus i kun den menneskelige natur), er Luthers ministerium verbi-embede en repræsentation af den inkarnerede Kristus, den kødeliggjorte Logos. Luthers stærke inkarnatoriske gudsforståelse, at Gud vil kendes som menneske og meddeler sig gennem Ordet, må nødvendigvis få følger for embedsteologien. Embedet fordrer et (uddannet) menneske.

En lang række kvinder i det 16. århundrede og senere tager Luthers teologi alvorligt og agerer efter den, også som prædikanter. ${ }^{28}$ Men ligesom reformationen møder mange vanskeligheder, møder også de megen modstand, og med formaliseringsprocessen i generationen efter Luther øges modstanden. ${ }^{29}$ Der går godt 400 år, inden Luthers reformatoriske tanker om embedet bliver løst fra en kønsbinding, fordi hele samfundstænkningen og et uddannelsessystem, der giver adgang for kvinder på højeste niveau, skal være på plads.

\section{Embedet skifter køn: loven af 1947}

Den 4. juni 1947, 430 år efter reformationens begyndelse og fem år efter Det Teologiske Fakultets grundlæggelse ved Aarhus Universitet, underskrev kong Frederik IX to lovændringer. Først og fremmest afskaffedes den spærreparagraf, som rigsdagen havde vedtaget i 1921, to år efter, at spørgsmålet om kvindelige præster første gang blev rejst i rigsdagen som led i den generelle ligestilling mellem kvinder og mænd med hensyn til offentlige hverv. Hvor der tidligere ikke havde været nogen lov, blev kvinder i 1921 gennem politisk indgriben pludselig ved lov forment adgang til "Embeder, hvortil kræves Præstevielse." ${ }^{30}$ I 1947 fjernede politikerne ganske enkelt den ind-

28. Se Roland H. Bainton, Women of the Reformation. In Germany and Italy [1971]; Women of the Reformation. From Spain to Scandinavia [1977] (Fortress Press 2007); Kirsi Stjerna, Women and the Reformation (Blackwell Publishing 2009).

29. Se fx Lyndal Roper, The Holy Household. Women and Morals in Reformation Augsburg (Oxford: Clarendon Press 1989).

30. Jeg trækker her og i det følgende på min bog, Else Marie Wiberg Pedersen (red.), Se min kjole. Om de forste kvindelige prosters historie (København: Samleren 1998), hvor de omtalte love er gengivet i “Appendiks A". Jf. August Roesen, Kirkelove (København: Lohses Forlag 1961), 153-156. Bogen blev udgivet i anledning af 50 -året for den første officielle ordination af (tre) kvindelige præster i den danske 
skrænkning af adgang til præsteembedet, som de selv havde indført i 1921 på trods af, at en høring hos justitsministeriet, Det teologiske Fakultet og biskopperne viste, at der hverken var retlige, skriftmæssige, bekendelsesmæssige eller principielle indvendinger mod kvindelige præster (Pedersen 1998, 108-118). ${ }^{31}$

Desuden blev også en lov om adgang til præsteembeder i folkekirken vedtaget af rigsdagen i 1941 revideret. Her ændredes alene et substantiv og et pronomen, idet substantivet "mænd" ændredes til "personer", og pronomenet "han" ændredes til "den pågældende". Den ikke før forekommende binding af embedet til mandekønnet skete i 1920, da rigsdagen vedtog en midlertidig lov til afhjælpning af præstemangel, som samtidig løsgjorde embedet fra kravet om en teologisk universitetsuddannelse. I modsætning til Kirkeordinansen af 1539, der binder embede og "retsindig lærdom" eksplicit sammen, men ikke embede og mandekøn. ${ }^{32}$ I 1947 neutraliserede politikerne altså deres egen sprogbrug og gjorde adgangen til folkekirkens præsteembede kønsneutralt. Samtidig indsatte man en ekstra paragraf, der understregede menighedsrådenes frihed til at vælge præst.

Lovændringerne, som neutraliserer kønnet, betyder, at folkekirkens medlemmer har fàet større frihed til at vælge og kalde den præst, de ønsker. Man er gået fra lov tilbage til evangelium.

\section{Har ordinationen et køn?}

Lovændringerne førte til, at de første tre kvinder blev ordineret til præstestillinger inden for folkekirken; og selvom antallet af kvin-

folkekirke i 1948 og giver den første samlede fremstilling af hele historien bag og debatten om de første kvindelige præster. Bogen (Pedersen 1998) rummer således både en kirkeretlig-kirkepolitisk og en kvindehistorisk redegørelse for udviklingen fra 1918-1948, samt en analyse af teologien bag debatten og udviklingen før og efter 1948. Desuden bringer den analyser af virkningshistorien i relation til såvel præsterollen som prædikantrollen. Jeg tager problemstillingen frem igen i denne artikel, dels i anledning af 70-året for lovændringerne, dels for at belyse den for yngre generationer, som ikke kender hverken historien eller teologien bag, hvad der (foruden menighedsloven af 1903) var det vigtigste nybrud i det 20. århundredes danske teologi og kirkeliv.

31. Marianne Rasmussen, "Da Mand blev til Personer", Pedersen 1998, 108-143 (108-118).

32. Se Martin Schwarz Lausten, Kirkeordinansen $1537 / 39$ (København: Akademisk Forlag 1989), 188-193. Fx formuleringen: "De Sognepræster, som ere nu saaledis forordinerede til den aandelige tienise at Predicke Euangelium, maa saa lengi actes oc kalles det de ere, som de bliffue warafftige vdi resindige lærdom oc gode seeder oc et ærligt leffnet" (193). 
delige præster voksede meget langsomt de første årtier efter, er ca. halvdelen af folkekirkens præster i dag, 70 år senere, kvinder. $\mathrm{Nu}$ heldigvis næsten uden at nogen bemærker, hvilket køn embedspersonen har, men der har bestemt været megen polemik både før og efter 1947. 514 præster protesterede i 1947 mod lovændringerne, idet de anså ordinationen af kvinder for at være en "skismatisk handling" (Pedersen 1998, 195). ${ }^{33}$

Der er i det hele taget opstået et mærkeligt spørgsmål om ordinationen, som kan føres tilbage til debatten i 1920-21. Ligesom det skete senere med spørgsmålet om homoseksuelle vielser, opstod problemerne, da kirkeudvalgets formand, Elna Munch, rejste spørgsmålet, om ordinationsritualet i tilfælde af ordination af kvindelige præster skulle ændres helt, eller om det ville være nok med formelle ændringer. ${ }^{34}$ Køn overskyggede sagen, og debatten resulterede i et kunstigt skel mellem spørgsmålet om kvindelige præster og spørgsmålet om ordination af kvinder. På grund af den herskende præstemangel, og ikke mindst i erkendelse af behovet for kvindelige præster i særlige situationer, advokerede såvel kirkeudvalg som biskopper nemlig for ansættelse af lønnede men ikke-ordinerede kvindelige medhjælpere ved kvindefængsler, kvindeafdelinger på hospitaler og lignende institutioner. Problemet var for dem alene ordinationen, som havde fået en særlig status. Man indførte en skelnen mellem, hvorvidt kvinder kan fungere som præster, og hvorvidt kvinder kan modtage ordinationen. Det var ikke det første, men det andet, altså ordinationen af kvinder, der var det virkelige problem dengang som nu for højreføjen, jf. ovenfor. Den konservative del af kirken protesterede derfor ikke, da politikerne de facto og de iure greb ind i kirkens indre anliggender $\mathrm{i}$ 1920 ved at tillade ikke-teologiske mænd som ordinerede præster, ${ }^{35}$ og heller ikke i 1921 ved at udelukke kvinder som ordinerede præster. Lovændringen af 1947 ophæver imidlertid ikke det mærkelige spørgsmål om ordination. I kombination med en vid forståelse af (mandlige) embedspersoners, biskoppers og præstekollegers samvittighedsfrihed blev ordination af kvindelige præster et særligt overophedet tema.

33. For adressen af 28. februar 1947 i sin helhed, se Presteforeningens Blad (1947), 199-200. De vigtigste citater herfra findes i Else Marie Wiberg Pedersen, "Når præsten er ' $k ø n$ '. De såkaldte teologiske argumenter i debatten om kvindelige præster", Pedersen 1998, 189-222 (194-195).

34. Se Else Marie Wiberg Pedersen, "Biskoppen, hun...", Folkekirkens Embeder. Kirkeretsantologi 2011, red. Kirsten Busch Nielsen m.fl. (København: Forlaget Anis for Selskab for Kirkeret 2011), 102-103.

35. Der var ikke en høring blandt menighedsråd om dette spørgsmål, og heller ikke en kaldelse fra nogen menighed, sådan som kravet er ved spørgsmålet om kvindelige præster. 
For det første kan en kvindelig kandidat være kaldet til en menighed i et stift, hvor biskoppen ikke vil ordinere. Derfor skabes Biskoppernes Fritagelseslov, vedtaget 3. marts 1948, hvorved en biskop kan bede sig fritaget fra at ordinere og en anden træde i hans (eller hendes) sted. Den nye lov gør ordinationen af to af de tre første danske, kvindelige præster mulig. Da biskoppen over Fyn, Hans Øllgaard, 28. april 1948 ordinerede Edith Brenneche Petersen til en stilling som hjælpepræst i Nr. Aaby-Indslev, ordinerede han også Johanne Andersen, kaldet til en valgmenighed på Lolland-Falster, og Ruth Vermehren, allerede fungerende præst ved kvindefængslet (Christianshavn). Ved ordinationen fremhævede Øllgaard kvindernes funktion som opstandelsesvidner (Matt 28,5-10) og satte tjenesten ind under evangeliet, hvorved han rehabiliterede embedet som en sendelse af de troende til at forkynde dette evangelium. En sådan stiftsbåndsløsning blev atter aktuel, da den fjerde kvindelige præst, Helga Jensen, i 1955 skulle ordineres til en stilling som personlig hjælpepræst for sognepræsten i Skive, Fiig-Pedersen. Biskoppen over Viborg Stift, Christian M. Baun, og en af de 514 protesterende præster i 1947, vægrede sig af de såkaldte samvittighedsgrunde mod både ordination og tjenstlig kollats såvel som mod at lade en biskop ordinere den kvindelige præst. ${ }^{36}$ I lang tid fastholdt de øvrige biskopper af kollegiale grunde derfor, at Helga Jensen enten måtte fortsætte som uordineret hjælpepræst eller forflyttes til et andet stift. Det var i langt højere grad kirkens rummelighed i forhold til modstanderne af kvindelige præster end kønnenes lighed i forhold til kirkens menigheder, der optog de danske biskopper. Så først da Baun selv, efter lange forhandlinger med kirkeminister Bodil Koch og de øvrige biskopper, frasagde sig det biskoppelige tilsyn med Skive, ordinerede biskoppen over Aalborg Stift, Erik Jensen, den 15. februar 1956 Helga Jensen. I en erkendelse af, at der hverken var økumeniske eller andre saglige hensyn, der talte imod ordination af en kvindelig præst, blev han dermed den anden biskop, der ordinerede en kvindelig præst. Når det blev sidste gang, loven om stiftsbåndsløsning blev taget i brug, skyldtes det, at Luthers embedsteologi om forholdet mellem det almindelige præstedømme og den særlige forkyndelsestjeneste, bedst udfoldet i "De instituendis ministris ecclesiae" fra 1523, endelig blev fuldt realiseret. Menighederne havde fåt øjnene op for omfanget af deres ret og pligt til at kalde en præst, som var dygtig og duelig præcis hos dem; og de kvin-

36. For en detaljeret gennemgang af sagen og forhandlingerne, se Lis Bisgaard, "Debatten om kvindelige præster", Pedersen 1998, 185-187, og Ole Hyldegaard Hansen, "Fra undtagelsesregel til undtagelsestilstand. Politiske og kirkelige hensyn til modstandere af kvindelige præster 1947-2007”, Kirkehistoriske Samlinger 2013, 177-184. 
delige teologer havde gennemført nøjagtig samme lange universitetsuddannelse, som de mandlige, måske endda med bedre resultater. Det ville ind i den faktiske kontekst være en skandale at vedblive med at tilsidesætte højtuddannede kvindelige teologer og dermed "dygtige folk." ${ }^{37}$ Spørgsmålet om ordination af og tilsyn med kvindelige præster var nu et tema ved bispevalg. Temaet var centralt allerede samme år ved bispevalget i Haderslev Stift, hvor vinderen, Frode Beyer, dog gik af med sejren med en erklæring om, at han ønskede "frihed til at handle under ansvar" ${ }^{38}$ mens modkandidaten havde erklæret sin fulde tilslutning til at ville følge menighedens ønske om en kvindelig præst og derfor uden tøven ordinere hende. Men ved bispevalget $i$ Fyns Stift i 1958 var en positiv holdning til ordination af kvindelige præster afgørende (Hansen 2013, 185-186).

For det andet kan en kvindelig præst være kaldet til en menighed i et stift, hvor der findes mandlige kolleger, der af de såkaldte samvittighedsgrunde er modstandere af kvindelige præster og ikke vil hilse på dem ved ordination. For at tage hensyn til modstanderne af kvindelige præster herskede der fra 1947 til 2007, altså i 60 år, en særlig undtagelsesregel, de sidste to årtier dog kun i Viborg Stift, der fritog dem fra at give kvindelige præster et kollegialt håndslag (Hansen 2013, 167-202). Denne sidste særordning blev opfattet som et ritualbrud, efterhånden som hverken kvindelige præster eller kvindelige biskopper hørte til undtagelsen i den danske folkekirke.

\section{Kun for mænd: Prenter om kvinden og det kirkelige embede}

Ved 10-årsjubilæet for de første ordinationer af kvindelige præster tog tre fynske præster - Johannes I. Hansen, Dag Monrad Møller og Verner Schroll - initiativ til bogen Kvinden og Kirkens embede. ${ }^{39}$ De tre præster (som alle i 1948 søgte stiftsbåndsløsning, men fik afslag, fordi de ikke havde rådført sig med deres menigheder) opfordrede

37. Jf. Luther, WA 50, 633.

38. Dannevirke 20.1. 1956.

39. Johs. I. Hansen, Dag Monrad Møller og Verner Schroll, Kvinden og kirkens embede. En meningsudveksling mellem pastor Dag Monrad Moller, pastor Johs. I. Hansen, pastor Verner Schroll, professor Regin Prenter og biskop Halfdan Høgsbro (København: Nyt Nordisk Forlag/Arnold Busck 1959). I Sverige, hvor den første ordination af kvinder skete i 1958, udkom en lignende debatbog i 1990: Per Erik Person og Bengt Holmberg, Tjänare åt evangelium (Stockholm: Verbum 1990). Men begrundelsen for denne publikation var ikke en tilbagekaldelse af ordination af kvinder. Den var et ønske om at gøre yngre generationer bekendte med teologien bag og selv reflektere over kirkens fremtid (7-9). 
i 1958 såvel alle biskopper i folkekirken som professor i dogmatik, Regin Prenter, til at genoverveje ordinationen af kvinder. Prenter blev i bogen fortaler for modstanden mod kvindelige præster. Som repræsentant for tilhængerne af kvindelige præster stod biskop Halfdan Høgsbro, Lolland-Falsters Stift, som var den eneste biskop, der ønskede at deltage. Særligt vigtigt har det været for de tre fynske præster at få Prenter til at uddybe den betænkelighed ved ordination af kvindelige præster, han tidligere havde givet udtryk for.

Anledningen til bogens tilblivelse var et nyligt overstået bispevalg på Fyn, hvor ordination var blevet tematiseret som biskoppens vigtigste handling i forhold til menigheders og menighedsråds frihed til at vælge præst. Dertil kom, at de fandt en nylig stedfunden ordination af en kvindelig præst, ligeledes på Fyn, var foregået uden "almenkirkelig concensus" (Hansen m. fl. 1959, 9). Præsternes debatoplæg rummede tre spørgsmål, som hovedsageligt var en genfremførelse af de kendte argumenter fra debatten 1918-1948. Det drejede sig om 1) ordinationen som en ældre praksis; 2) fælleskirkelig konsensus om ordinationen og 3) embedet som apostolsk og således udtryk for en apostolsk succession (9-12).

De tre fynske præster anser ordination af kvinder for at være en uacceptabel, ny praksis og spørger til to hjemler. Først hvilken teologisk-liturgisk hjemmel biskopperne mon har benyttet sig af. De finder, at den af biskopperne anvendte ordlyd ved ordinationsritualet er i strid med Pastoralbrevene, navnlig Titus 1,5-9, og Kirkeordinansen af 1539, netop fordi termen "mænd" er blevet udskiftet med termen "personer". De tre præster er overbevist om, at der er en "nøje theologisk-liturgisk sammenhæng" her med forståelsen af prædikenembedet som et embede for mænd alene, og at dette afspejles i Den Augsburgske Bekendelse og andre reformatoriske kirkeordninger ( $f_{x}$ den svenske kirkeordning af 1571) (12). Dernæst spørger de til (b), hvilken kirkeretlig hjemmel, biskopperne lægger til grund for ændringen af ritualets ordlyd. De forstår ikke, hvorfor en ændring af ritualets ordlyd på dette punkt kan ændres uden en lovændring, når lovgivningen om kvindelige præster i 1947 krævede en sådan. På den baggrund har de bedt Prenter om at give sine kommentarer til en række spørgsmål og samtidig bedt alle danske biskopper om at svare på, om de ikke ved at lægge Rigsdagens lovændring til grund for det, de ser som en ritualændring, har ladet staten bestemme i et indrekirkeligt spørgsmål (13).

Prenter, som i vore dage er mest kendt for sin skabelses- og helligåndsteologi, som den kom til udtryk i en række publikationer, bl.a. i 
Skabelse og Genløsning fra 1951, ${ }^{40}$ samt for en genskabende tolkning af Luthers kristologi og korsteologi, var blandt sine kvindelige teologistuderende især kendt for sin modstand mod kvindelige præster. Det teologiske vidsyn og luthersk teologis samspil med navnlig anglikansk, men også romersk-katolsk teologi, som han stod for, slog i embedsteologien ud som et forsvar for den historisk episkopale succession, der i den katolske kirke stadig er en hindring for, at kvinder kan fungere som præster, og indtil 1992 var en hindring for kvindelige præster i den britiske anglikanske kirke. Det er bemærkelsesværdigt, eftersom han i sin dogmatik tilbagevendende omtaler den romerskkatolske kirke som "pavekirken" eller "pavens kirke" med brod mod kirkens "babyloniske fangenskab under papalismens falske overherredømme" (Prenter 1951, 164-172) og udtrykker heftig modstand mod den apostolske succession i en romersk-katolsk eller anglikansk form. ${ }^{41}$ Men i Kvinden og Kirkens Embede stiller sagen sig anderledes, og Prenter ser intet problem $\mathrm{i}$, at hans syn på embedet i modstanden mod kvindelige præster måske er anglikansk (og måske ligger tæt på Canterbury (126)), mens han helst ikke vil stå ved en nærhed til Rom, sådan som Høgsbro anser hans synspunkter på sagen for at gøre $(109,145)$.

I sin ledsagende erklæring til bogen tager Prenter fat om de tre præsters spørgsmål med en argumentation, der er rodfæstet $i$ et meget traditionelt, feudalt og i alle måder antidemokratisk embeds- og kirkesyn. De enkelte svar udfoldes yderligere i dialogen med Høgsbro. Om det første spørgsmål hævder Prenter, at der med ordination af kvindelige præster er tale om "et brud med en århundredgammel tradition i den danske kirke" (14). Den gældende lovgivning om kvinders udelukkelse fra præsteembedet hvilede, ifølge Prenter, på den forudsætning, at borgerlig og kirkelig orden var uafhængig af hinanden. Lovændringen af 1947 var derfor et dobbelt brud med traditionen: Dels brød man med "det gældende præstevielsesrituals opfattelse af det kirkelige embede som et mandligt embede" (15). Dels brød man med den fra reformationstid og enevælde gældende opfattelse, at staten kun kan lovgive i ydre kirkelige sager (ius circa sacra), ikke i interne kirkelige sager (ius in sacra). Prenter hævder dermed, at Folketingets lovændring er indblanding $\mathrm{i}$ indre-kirkelige sager uden nogen form for teologisk begrundelse, der rækker ud over private udtalelser. Han anerkender således ikke ændringen af "den århundredgamle

40. Regin Prenter, Skabelse og genløsning. Dogmatik (København: G.E.C. Gad 1951).

41. Se bl.a. Regin Prenter, "Catholic and Evangelical. A Lutheran View", Ecumenical Review 1 (1949), 384-385; Prenter, Protestantismen i vor tid (København: H. Hirschsprungs Forlag 1957), 100-102. 
praksis", da ordination af kvinder øver vold mod ritualets bogstav såvel som ånd (15-16). Uden nærmere indsigt i sagen mener Prenter, at det ritual, som de kvindelige præster ordineres efter, må være ugyldigt. Han er sikker på, at en ritualændring må have fundet sted, da embedssynet nu ifølge ham er nyt:

For at ordination af kvinder skulle kunne foregå fuldt lovformeligt, forekommer det mig, at der på normal vis måtte have været foretaget de ændringer i det gældende ordinationsritual, som var nødvendige for at bringe dets ordlyd og tankegang i overensstemmelse med det nye syn på præsteembedet. At det ville være vanskeligt at finde en brugbar skriftbegrundelse til et sådant nyt ritual, er en anden sag. Noget sådant er imidlertid ikke sket. Hvilket ritual kvinder ordineres efter, er mig ubekendt, da der ikke er tilgået offentligheden nogen meddelelse herom - men et i kirkelig forstand gyldigt ritual kan det næppe have været (16).

Prenter går altså ud fra, at ordinationerne af kvindelige præster er ugyldige, og endda ulovlige, selvom han (selvforskyldt, da han ikke vil medvirke ved ordinationer af kvinder) ikke har kendskab til dem. Det er i denne forbindelse vigtigt at understrege, at Prenter helt forbigår det forhold, at det såkaldte forbud mod kvindelige præster i den danske kirke som sådan ikke er århundredlangt. Som nævnt, kom en egentlig udelukkelse af kvinder ved lov først i kraft af politisk indgriben i henholdsvis 1920 og 1921. Desuden er det af stor vigtighed at bemærke, at når Prenter hævder, at der ikke har været hverken et kirkeretlig eller et liturgisk grundlag for lovændringen, så forbigår han, at spørgsmålet om kvindelige præster blev behandlet og diskuteret $\mathrm{i}$ mere end 30 år, de 29 med varierende intensitet fra politisk side, men altid med inddragelse af universitetsteologerne, juraen og medlemmerne af folkekirken. Dertil kommer, at man samtidig vedtog en lov, der tillod ikke-uddannede mænd at blive præster, hvorved både kirke og stat brød med Luthers princip om, at præsteembedet ikke skulle besættes af udygtige mænd. ${ }^{42}$

Prenters hovedanke er således, at man har forladt "det hævdvundne" i synet på præsteembedet (15), som for ham er en sakramental opfattelse af embedet som et udelukkende mandligt embede. Og mon ikke dette er sagens kerne, at et hævdvundet privilegium er mistet. Men han glemmer hermed, at både kirkens og samfundets struktur er ændret væsentligt siden enevælden. Argumentet, at embedet er et indre kirkeligt anliggende (ius in sacra), er meningsløst i en folkekirke, hvor præsterne er statsansatte. Det gælder også argumentet vedrørende

42. Luther, WA 50, 633. 
ordinationsritualets ordlyd. Ritualets anvendelse af pronominer og skriftsteder har ikke nogen tvingende dogmatisk endsige bibelsk begrundelse. I en luthersk forståelse er ritualer menneskeskabte og ikke uforanderlige (jf. CA 7).

Dernæst tager Prenter fat på spørgsmålet om konsensus og for at få ret fat om hans synspunkt på dette område, er det nødvendigt at bringe et længere citat, der viser hans forståelse af "luthersk tankegang":

Bag ved dette begreb [konsensus] ligger, hvis jeg har forstået Dem ret, vor kirkes bekendelses opfattelse af embedet som en guddommelig indstiftelse (CA V), hvortil menigheden på Guds vegne kalder gode og egnede mænd. Læren om "kaldelsen" til embedet er i denne genuint lutherske tankegang, hvorpå også de danske ordinationsritualer hviler, ret nuanceret og er ikke, som det i vor tid ofte høres, udtryk for en "demokratisering" af embedet (16).

I første række henviser citatet til CA og det, Prenter forstår ved "luthersk tankegang”, ikke til Luther selv. Prenter er ikke demokrat og hans fremstilling fremstår i denne sammenhæng snarere episkopal, især i en anglikansk aftapning, end luthersk. Ganske vist refererer han til sene reformatoriske tekster som Martin Chemnitz' Examen concilii Tridentini og det danske kirkeritual af 1685 og, først derefter, til Luther for hans "velkendte fremhævelse af, at ordets tjener er Guds udsending og ikke visse menneskers befuldmægtigede talsmand" (17). Med henvisning til Luthers Von der Winkelmesse und Pfaffenweihe fra 1533 (WA 38, 238,7) og Om koncilierne og kirken (WA 50, 632,36) mener Prenter at kunne påvise, at Luther forstod kaldelsen alene som Guds, ikke som menighedens, og helt uadskillelig fra ordinationen. Kaldelsen glider så at sige over i ordinationen, der for Prenter er det afgørende punkt.

I spørgsmålet om en fælleskirkelig konsensus plæderer Prenter altså for, at den kaldende menighed ikke blot skal forstås som en lokal menighed, men som den universelle menighed, samt at embedet må ses som guddommeligt indstiftet (jf. CA 5). Derfor kan han ikke anse spørgsmålet om kvinders adgang til præsteembedet som et adiaforon eller tidsbestemt. Imidlertid medgiver Prenter, at ordinationen af kvinder ikke primært møder modstand i Det Nye Testamente. For ham ligger problemet i den omstændighed, at embedet har en bestemt historisk given, traditionel egenart. For at stadfæste det mandlige embedes teologiske særstatus griber Prenter til en grov analogislutning: at ændre embedets egenart - det vil sige, at gå fra et embede 
eksklusivt for mænd til at indeslutte kvinder - er som at udskifte altervin med grapejuice (22).

Endelig henviser han til sendelsen af de 12 (Luk 9; par.) og af de 70 (Luk 10) samt af apostlene efter opstandelsen (Luk 24; par.) for at gøre gældende, at kirkens sendelse må skelnes skarpt fra kirken som "en menneskelig indretning til tilfredsstillelse af bestemte religiøse og moralske behov efter enhver tids fornuftige skøn" (23). Prenter sætter også her traditionen over skriften, sådan at hans embedssyn fremstår klart mere middelalderlig end reformatorisk. Prenter, som selv ofte henviser til middelalder og modreformationen, synes at være klar over vanskelighederne i sin position, og nogle spørgsmål, såsom det om konsekvensen for biskopper, der ordinerer kvindelige præster, undviger han (21-22). Det gælder også i spørgsmålet om sendelsen, at hans argumentation bliver uklar. Hvis Jesu sendelse udelukker kvinder, kan kvinder slet ikke være en del af hele kirken.

I spørgsmålet om embedets apostolicitet, som Prenter forstår som en ubrudt række mandlige udsendinge siden apostlen Peter, tager han atter udgangspunkt i den guddommelige indstiftelse (25-28, 5861). Hovedargumentet er, at Luther ikke ønskede et brud med "den gamle kirke", hvad embedet angik, kun hvad misbrug angik. Prenter fremfører derpå to analogislutninger. Først slutter han fra frelsen som et historisk faktum til evangeliet og sakramenterne som kirkens historiske kontinuitet (26). I denne analogi forstår Prenter utvetydigt embedet som et sakramente. Ligeledes ligger der under analogien en forstålse af embedet som en eksklusiv mandlig Kristusrepræsentation på linje med katolsk embedssyn. Hans forståelse af et mandligt embede som et sakramente bygger nemlig på den antagelse, at den mandlige præst qua sin mandlighed bærer Kristi historiske form som en mand og derved er tegnet på embedets hellige karakter.

Dernæst slutter Prenter indirekte fra katolicismens misbrug og reformationens sværmere til nutidens indlemmelse af kvindelige præster. Alt dette ses som "forfalskninger" af evangeliet, og senere føjes termer som "vranglære" og "frafald" til. Prenter benytter sig af en skolastisk argumentationsmåde. Indledningsvist anføres problemstillingen og den dertil knyttede tese, at traditionen bevares ved at afvise kvindelige præster. Dernæst følger argumentet ud fra traditionen, hvorefter anstilles de mulige indvendinger, som af Prenter afvises med sakramentepraksis samt de allerede nævnte analogislutninger. Endelig drages konklusionen, at kirkens hidtidige hævdvundne praksis har normativ karakter. Der er altså ikke i første række tale om Bibelen som målestok, og Prenter fremfører heller ikke sine argumenter som tvingende grunde. Hverken embedets væsen eller embedets 
funktioner taler imod, at en kvinde kan være ordets tjener. Afgørende er alene kønnet, fordi Kristus og apostlene var mænd.

Selvom Prenter flere gange gør gældende, at han godt ved, der ikke er tale om tvingende grunde, når han fremholder bibelcitater som bl.a. det klassiske Pauluscitat, at kvinder skal tie i forsamlinger (1 Kor 14,34), slutter han sit efterfølgende indlæg med at erklære, at "modstandere af kvindelige præster på bibelsk basis konsekvent må nægte at bruge kvindelige præster" (83). For ham gælder det, at "den situation, der er opstået i kirken ved denne uenighed, er og (fortsat) skal vedblive at være ufredelig, besværlig og pinlig på begge sider” (82). I et ekko af Indre Missions Chr. Bartholdys ord i 1949 (Bisgaard 1998, 183) erklærer han, at han vil forlade kirken, når en kvindelig præst møder op ved en ordination, samt at intet kirkeligt organ vil kunne beskytte kvindelige præster mod situationens ufred.

Krigserklæringen blev fulgt af modstanderne i de næste årtier, koblet med et tilbagevendende krav om særordination. ${ }^{43}$ Med en mærkelig argumentation, der både ville fastholde den sakramentale embedstradition, som Luther gjorde så voldsomt op med, og en bibelfundamentalisme, der gjorde sola scriptura til sola pars scriptura for kvinder, kan man sige, at det 20. århundredes modstandere af kvindelige præster var mere konservative i spørgsmålet, end Luther efter al sandsynlighed selv havde været, havde han levet i det 20. og ikke i det 16. århundrede. Især hævdelsen af mandligheden som et tegn på embedets sakramentale karakter står i total modsætning til Luthers forståelse af såvel kristologien som embedsteologien. I Prenters forståelse, modsat Luthers, er embedet sakralt og står over det almindelige præstedømme, som mister sin betydning. ${ }^{44}$ Kønnet er blevet afgørende, mens embedet er gjort til mere end en funktion og mere end et nådemiddel ved siden af ordet og sakramenterne: det er $\mathrm{i}$ sig selv et sakramente på linje med dåb og nadver.

43. Else Marie Wiberg Pedersen, “Når præsten er 'køn'. De såkaldte teologiske argumenter i debatten om kvindelige præster", Pedersen 1998, 189-222 (206-214). 44. Prenter har i flere publikationer foretaget sine kreative bøjninger af Luthers teologi, når det gælder embedet. Se bl.a. Prenter, Kirkens embede. Udkast til en det kirkelige embedes dogmatik med luthersk udgangspunkt (Aarhus: universitetsforlaget 1965); "Die göttliche Einsetzung des Predigtamtes und das allgemeine Priestertum bei Luther" [1961], Regin Prenter, Theologie und Gottesdienst. Gesammelte Aufsätze (Århus: Aros 1977), 207-221. 


\section{Afsluttende bemærkninger}

I anledning af 500-året for Luthers reformation er der på ny kamp om, hvad arven fra Luther er, og hvem der ejer den. Det skorter i den forbindelse ikke på kritikere, der mener, at Luthers reformation i virkeligheden var et tilbageslag, og at hans teologi betød en reduktion af kvinders muligheder i kirke og samfund.

Jeg har i denne artikel søgt at nuancere billedet ved at sætte Luther ind $\mathrm{i}$ hans egen kontekst. I dette perspektiv er reformatorens embedsteologi radikalt fornyende. Det er Luthers tanker om dåben som ordination, om kaldelse og det gensidige forhold mellem det almene embede og det særlige prædikenembede, samt den dermed sammenhængende humanisering af præsten, der fører til, at kvinder får adgang til ordets tjeneste og ordinationen. At der går godt 400 år før den fulde realisering af dette i Danmark og et flertal af lutherske kirker, mens et mindretal af lutherske kirker stadig forbyder kvinder ordination, skyldes ikke Luther. Det fremgår tydeligt af debatten 1918-1948 og senere, herunder Prenters indlæg. Der tilføjes nye argumenter, ofte i modstrid med Luthers teologi. Et særligt problem udgør kønnet som kategori. Diskussionen om kvinders adgang til embedet handler ikke om embedets karakter og indhold, men om køn. Derfor kan det mærkelige spørgsmål om en særlig ordination for kvinder opstå.

I anledning af 75-året for Teologi ved Aarhus Universitet og navnlig 70-året for kvinders adgang til ordination og præstetjeneste er der grund til at glæde sig over den udvikling, som reformationen banede vej for. I Danmark kan vi snart se de skildrede synspunkter mod kvindelige præster som arkaiske. Men man støder stadig på det synspunkt, at et valg mellem udelukkende kvindelige bispekandidater er "kontroversielt." ${ }^{45} \mathrm{Vi}$ skal aldrig gøre os færdige med at diskutere Luthers teologi og de vanskeligheder, der også findes. Vi skal fortsat bakse med, hvordan Luthers frihedsbegreb skal forvaltes konstruktivt, og hvordan man på en genuin måde kan arbejde med sola scriptura-princippet og så meget andet. "Ecclesia reformata semper reformanda est."

45. Sagt af en mandlig journalist i DR P4 d. 18 maj 2017, da de to mandlige bispekandidater til Lolland-Falsters Stift var ude efter første valgrunde. 